\title{
AN EASY TO USE DEVICE FOR LUBRICITY EXAMINATION
}

\author{
Zsolt Tiba ${ }^{1}$, Géza Husi ${ }^{2}$, Sándor Manó ${ }^{3}$, László Kiss ${ }^{3}$, Zoltán Jónás ${ }^{3}$, \\ László Nádházi ${ }^{1}$, Zoltán Csernátony ${ }^{3}$ \\ ${ }^{1}$ Department of Mechanical Engineering, Faculty of Engineering, University of Debrecen \\ ${ }^{2}$ Department of Electrical Engineering, Faculty of Engineering, University of Debrecen \\ ${ }^{3}$ Department of Orthopaedic Surgery, Medical and Health Science Center, University of \\ Debrecen \\ tiba@mfk.unideb.hu
}

\begin{abstract}
The stability of surgical metals implanted into patients is affected by human extracellular fluid that can enter between different components of the implant system. However data are missing on the lubricity properties of different human fluids/tissues. In our article we would like to present an easy and inexpensive device to perform and standardize implant lubricity measurements.
\end{abstract}

Keywords: lubricity, friction, machine design

\section{Introduction}

The stability of metal implants assembled from different constituents inserted into the human body is greatly affected by the human extracellular fluid penetrating between the components.

For example according to our knowledge in case of the spinal implants the standard examinations $^{1,2}$ do not specify the examination conditions, they only state the examination can be performed in air, simulated body fluid, physiologic saline, or any other environment. However in the literature we could not find anything about the effect on stability caused by human extracellular fluid getting between the metal constituents. The manufacturers also determined the parameters required for assembly in vitro.

According to our opinion the standardization should also specify the examination environment, so that all the measurements can be compared, because our hypothesis is that lubrication has a considerable effect on the stability of the different montage. The best example for this is the implants used in the surgical correction of scoliosis deformity, where we construct a montage to exert immense force sometimes from over a dozen components. Therefore because during surgery the penetration of human extracellular fluid in between these components is unavoidable we find it important to determine the stability after lubrication. The industry uses sophisticated and expensive methods to determine this, and the examination environment is also completely different that is why we developed a simple equipment with which we can repeat and document the lubricity of different materials. Our further goal is to determine the relative lubricity of the previously mentioned biological fluid and to find its analog in industrial lubricants so we can standardize our measurements.

\section{Methods and Materials}

When developing the equipment it was important that the examined fluid does not elude from the examined surface facing each 


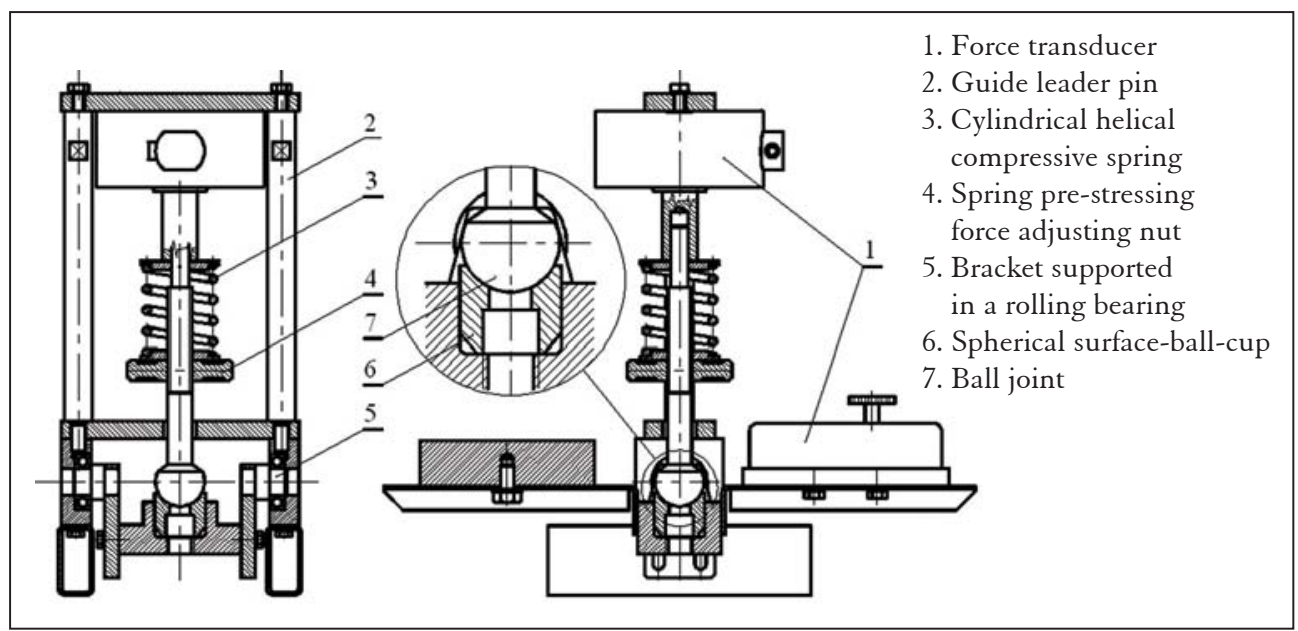

Figure 1. Assembly drawing of the test equipment

other. Due to the fact that this is hard to achieve with two flat surfaces we made a polished spherical ball and socket connection.

The assembly drawing of the equipment can be seen in Figure 1 and the photo of it in Figure 2.

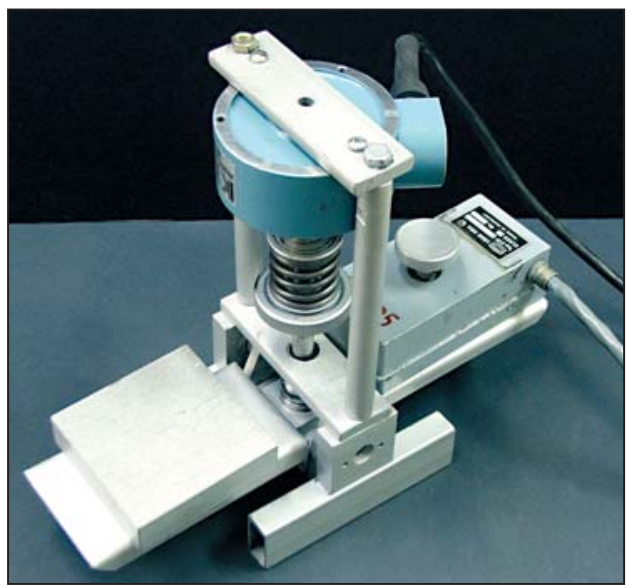

Figure 2. Photo of the test equipment

The material of the spherical surface-ball-cup is acid-proof steel, polished to an average surface roughness of $R_{a}=0.40$. The force pressing the surfaces can be adjusted by preten- sioning a cylindrical helical compressive spring. It was necessary, because despite the fact that theoretically the centre points of the spherical surface and the ball-cup coincide, because of the manufacturing tolerance (inaccuracy), the ball-joint could become stuck in the case of the ball-cup's displacement.

\section{Usage of the machine}

The basic concept of the equipment is that opposite a fixed steel sphere is a totally congruent mobile hemisphere. The magnitude of the force between the two surfaces can be modified through the aid of a spring and can be measured with a dynamometer. The hemisphere is connected to a ball-bearing axle through an arm, the force required to move the arm can also be measured through a dynamometer. The dynamometers are connected to a computer and the measured results can be saved. This apparatus is brought into motion by the torque $\left(\mathrm{M}_{\mathrm{e}}\right)$ generated by the force. In the beginning this torque is resisted by the frictional force $\left(\mathrm{M}_{\mathrm{s}}\right)$, but as we increase the force we achieve a point where $\mathrm{M}_{\mathrm{e}}$ will be greater then $M_{s}$ and the apparatus moves. 
Due to the fact that frictional force during movement is smaller than that during rest we will measure a lower value while in motion. The equipment can be used to compare measurements. The force required to move the apparatus is adjusted by hand.

This measuring background is available in the Machine-elements laboratories at the Faculty of Engineering, University of Debre$\mathrm{cen}^{3,4,5,6}$. The force transducers are connected with an amplifier (Spider 8), of which measuring frequency can be adjusted. Numerical data of the electrical signals, which can be saved and retrieved, are input in a database. The data, saved in the database can be evaluated by a measuring program, called CATMAN, which allows the graphical representation of the results. The program is able to represent the data as a function of time or as instantaneous values.

\section{Results}

We planed, manufactured and assembled the measuring equipment, fixed the dynamometers on it, connected it to a computer and performed preliminary measurements with it. The veracity of the measurements is insured by the calibrated dynamometers, but the results can not be validated by other presently used equipment, because those measurements were made at a higher speed and/or higher temperature domain. At the same time to ensure the repeatability of the measurements using our equipment we performed a series of measurements during which we examined the torque required to overcome friction with a force of $700 \mathrm{~N}$ in case of Vaseline (Figure 3).

Based on the 50 measurements we can confirm that the average torque required was $3.954 \mathrm{Nm}$, with a scatter of $0.125 \mathrm{Nm}$, which is $3.4 \%$ of the average.

\section{Discussion}

Due to the fact that only sophisticated and expensive equipment is available for the lubricity measurements of different materials, we felt the need to develop a simple but at the same time reliable way to perform these measurements. We developed an easy to use and based on preliminary measurements reliable equipment. We plan to use our device in the future for the rheological measurement of biological materials.

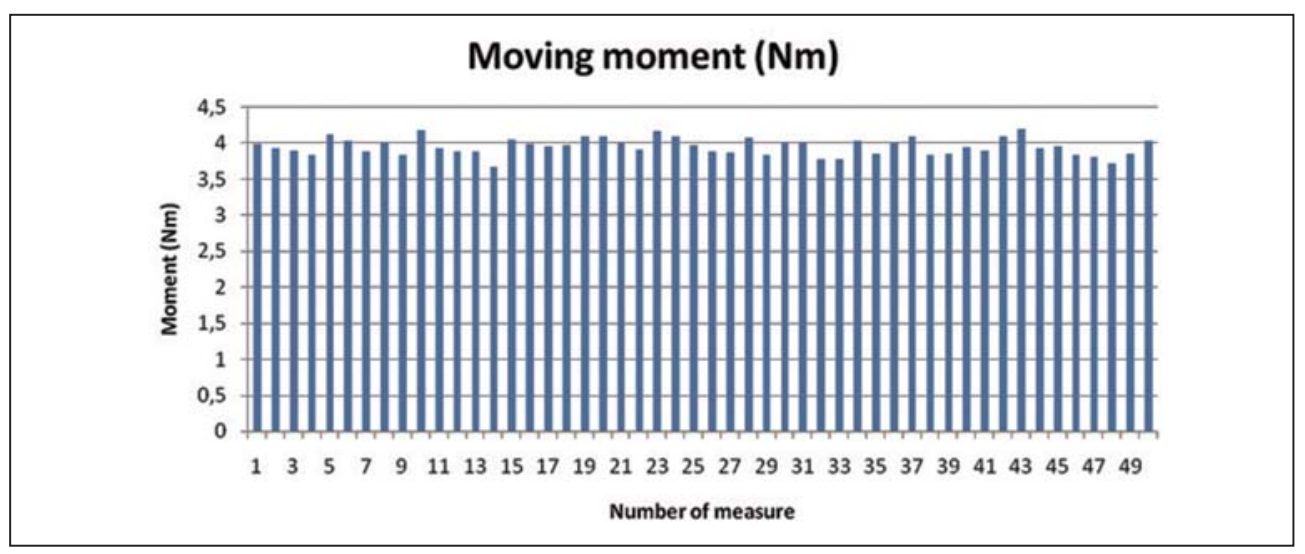

Figure 3. The results of the serial measurement to confirm repeatability 


\section{REFERENCES}

1. ASTM F1798-97 Standard Guide for Evaluating the Static and Fatigue Properties of Interconnection Mechanisms and Subassemblies Used in Spinal Arthrodesis Implants.

2. ASTM F1717-09 Standard Test Methods for Spinal Implant Constructs in a Vertebrectomy Model.

3. Tiba Zs, Hagymássy Z. Laboratóriumi foglalkozások szerepe a gépelemek tárgy oktatásában. Gép 1999;10:45-7.
4. Tiba Zs, Budai Z. Mérések a Gépelemek Laboratóriumban. DE MFK Tudományos Közlemények 2000;289-94.

5. Tiba Zs. Notwendigkeit der Modellbildung und Simulation bei der Dimensionierung mechanischer Konstruktionen. DE MFK Tudományos Közlemények 2002;1:117-25.

6. Fazekas L, Kisdeák Z, Tiba Zs. Some questions on the purity of hydraulic machine fluids. Manufacturing Engineering University of Technology in Kosice 2006;1:23-6.

\section{Dr. Zsolt Tiba}

Department of Mechanical Engineering, Faculty of Engineering, University of Debrecen H-4028 Debrecen, Ótemetô u. 2-4.

Tel.: (+36) 52 422-088

\section{MORDON}

\section{EgÉSZSÉGÜGYI ÉS INNOVÁCIÓS BETÉTI TÁrSASÁG}

\section{Orvostechnikai müszerfejlesztés, implantátumfejlesztés, tesztelés, valamint kiadványszerkesztés, kiadói tevékenység}

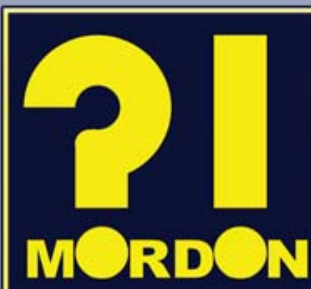

4275 Monostorpályi, Liget tanya, Bortnyák major

06 30/412-59-47

ucak@freemail.hu 